\title{
Review: the cellular mechanisms underlying mammary tissue plasticity during lactation in ruminants
}

\author{
M. Boutinaud ${ }^{1 \dagger}{ }^{\text {, L. Herve }}{ }^{1}$, H. Quesnel ${ }^{1}$, V. Lollivier ${ }^{1}$, L. Finot ${ }^{1}$, F. Dessauge ${ }^{1}$, E. Chanat ${ }^{1}$, \\ P. Lacasse ${ }^{2}$, C. Charton ${ }^{1 a}$ and J. Guinard-Flament ${ }^{1}$ \\ ${ }^{1}$ PEGASE, INRA, Agrocampus Ouest, 35590 Saint-Gilles, France; ${ }^{2}$ Sherbrooke Research and Development Centre, Agriculture and Agri-Food Canada, 2000 College \\ Street, J1M 0C8 Sherbrooke, QC, Canada
}

(Received 15 November 2018; Accepted 19 February 2019)

\begin{abstract}
The mammary tissue is characterized by its capacity to adapt in response to a wide variety of changing conditions. This adaptation capacity is referred to as the plasticity of mammary tissue. In dairy ruminants, lactation is challenged by modifications that can either be induced on purpose, such as by modifying management practices, or occur involuntarily, when adverse environmental constraints arise. These modifications can elicit both immediate changes in milk yield and composition and carryover effects that persist after the end of the challenge. This review focuses on the current knowledge concerning the cellular mechanisms underlying mammary tissue plasticity. The main mechanisms contributing to this phenomenon are changes in the activity and number of mammary epithelial cells (MECS). Changes in the number of these cells result from variations in the rates of cell proliferation and death as well as changes in the rate MEC exfoliation. The number of MECs also depends on the number of resident adult mammary stem cells and their progenitors, which can regenerate the pools of the various mammary cells. Several challenges, including changes in milking frequency, changes in level of feed supply and hormonal manipulations, have been shown to modulate milk yield together with changes in mammary cell activity, turnover and exfoliation. Epigenetic changes may be an additional mechanism of adaptation. Indeed, changes in DNA methylation and reductions in milk yield have been observed during once-daily milking and during mastitis in dairy cows and may affect cell activity persistently. In contrast to what has been assumed for a long time, no carryover effect on milk yield were observed after feed supply challenges in dairy cows and modification of milking frequency in dairy goats, even though the number of mammary cells was affected. In addition, mammary tissue plasticity has been shown to be influenced by the stage of lactation, health status and genetic factors. In conclusion, the cellular mechanisms underlying mammary tissue plasticity are diverse, and the mammary tissue either does or does not show elastic properties (with no permanent deformation), in response to environmental changes.
\end{abstract}

Keywords: dairy ruminant, mammary gland, review, adaptation, milk production

\section{Implications}

Lactation in dairy ruminants is challenged by perturbations that can either be induced on purpose, such as by modifying management practices, or occur involuntarily, when adverse environmental constraints arise. These challenges can have immediate effects on milk yield and could be followed or not by carryover effects. A series of studies have investigated the cellular mechanisms involved in the process of adaptation of the mammary tissue to these challenges. An improved understanding of these mechanisms may help predict irreversible effects on the mammary tissue.

\footnotetext{
a Present address: Department of Agricultural Biotechnology and Research Institute of Agriculture and Life Sciences, Seoul National University, Seoul, Republic of Korea.

${ }^{\dagger}$ E-mail: marion.boutinaud@inra.fr
}

\section{Introduction}

During a female mammal's life, the mammary gland undergoes many changes in size, structure, composition and activity. In dairy ruminants, females are subjected to successive reproductive cycles, and the mammary tissue adapts as it goes through the gestation, lactation and involution phases. During a normal lactation cycle, milk production follows a lactation curve (a strong increase up to a peak and then a gradual decrease) resulting from modulations of both the activity and the number of mammary secretory cells (Capuco et al., 2001). Meanwhile, the mammary gland responds to perturbations that the animal must cope with. This organ is characterized by its capacity to adapt in response to changes to a wide variety of conditions. This adaptation capacity is referred to mammary tissue plasticity. 
The mammary tissue plasticity is a component of the robustness of the animal that can be defined as the ability of an animal to adapt to environmental constraints (Friggens et al., 2010).

Several transient external perturbations can challenge the lactating mammary gland. The word 'challenge' is used in order to conceptualize the action of an external perturbation that exercises a constraint to the 'mammary tissue' system and can stimulate or impair lactation. In sciences other than biology, scientists have questioned how a system can adapt to changing conditions (Sauvant and Martin, 2010). The concepts developed in economics can be transposed to conceptualize how a biological system can adapt to challenges (Sauvant and Martin, 2010). When an animal is subjected to a challenge, the mammary tissue sets up an adaptive response that involves biological processes, and the production of milk can be affected. The mammary tissue is thus a deformable system, characterized by its resistance and its resilience (Figure 1). Resistance could be defined as its ability to tolerate a disruption induced by a challenge and can be illustrated by the difference in milk yield before and during the application of the challenge. Resilience could be defined as the ability of a system to return to its initial state when a challenge is finished. The resilience of the mammary tissue can thus be characterized by the carryover effects on milk yield (Figure 1). If no carryover effect is observed (the system goes back to its initial state), then the mammary tissue shows elastic properties. In contrast, if some carryover effects are observed (milk yield remains different from before the challenge), then the mammary tissue shows flexible properties. Our assumption is that understanding the cellular mechanisms underlying the adaptation of the mammary tissue during the application of challenges could make it possible to understand why there are carryover effects on milk yield or not. The objective of this review is, therefore, to contribute to a better understanding of the cellular and molecular mechanisms involved in mammary tissue plasticity. We will limit the review to the mammary tissue and, particularly, to the mammary epithelial cells (MECs) to simplify the system, even though it is obvious that the challenges also lead to wide physiological modifications at the wholebody level (effects on blood flow, nutrient and hormone concentrations etc.). In this review, we will first describe the indicators of the potential mechanisms involved in mammary tissue plasticity. We will, then, describe how these mechanisms could be affected during the application of diverse challenges. And, finally, we will address the question of the carryover effects when the challenge is finished.

\section{What are the indicators of the potential molecular and cellular mechanisms underlying mammary tissue plasticity?}

Indicators of the secretory activity of the MECS

One of the main cellular mechanisms that may contribute to mammary tissue plasticity is the changes in the secretory

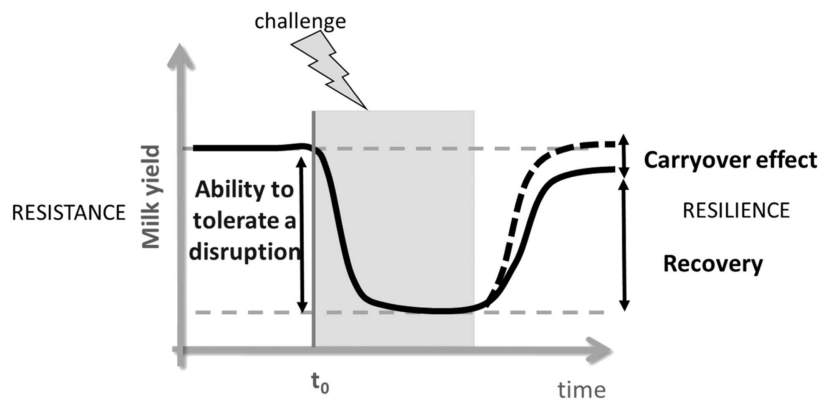

Figure 1 Schematic representation of the effect of a challenge (represented here with a negative effect on milk yield) on mammary tissue plasticity during lactation in ruminants as indicated by the variation in milk yield. The grey box indicates the phase when the challenge is applied, and $t_{0}$ corresponds to the time zero of the application of the challenge. The adaptation of the mammary tissue when animals are challenged during lactation can be characterized by an initial resistance phase followed by a resilience phase (Adapted from Sauvant and Martin, 2010).

activity of the MEC. The secretory activity of MEC can be analyzed in terms of enzyme activity and target-gene expression and using global transcriptomic or proteomic approaches. MECs express messenger RNA (mRNA) coding for milk-specific proteins and proteins necessary for the synthesis of milk constituents (enzymes, transporters, receptors, intra-cellular messengers etc.). Microarray and KEGG pathway analyses were used to provide a picture of the transcriptomic adaptations in the mammary tissue between the end of pregnancy and the onset of lactation, showing an overall induction of the metabolism categories, with the 'lipid metabolism,' 'glycan biosynthesis and metabolism' and 'carbohydrate metabolism' pathways being the most impacted (Bionaz et al., 2012). Another way to study the secretory activity of MEC is to target genes of interest. The main target genes studied are the ones coding for milk components such as milk proteins like casein $\alpha \mathrm{s} 1$ type 1 (CSN1S1), $\alpha$ S1 type 2 (CSN1S2), $\beta$ - (CSN2), or $\kappa$ (CSN3) or $\alpha$-lactalbumin $(L A L B A)$. This last gene is particularly interesting because $\alpha$-lactalbumin is the co-factor of the enzyme galactosyltransferase (GT), which is involved in the last step of lactose synthesis. Since lactose is the main osmotic agent in most mammalian species, it has a prominent role in the determination of the volume of milk produced. Changes in mammary cell activity can also be shown through the activity of several key mammary enzymes, such as GT, acetyl-CoA carboxylase (ACC) and fatty acid synthase (FASN); the last two being involved in the synthesis of milk fat. It has been shown that the increase in milk production at the onset of lactation partly results from an increase in the activity of ACC, FASN and GT (Knight and Peaker, 1984). In addition, the proteome of milk or mammary tissue can also reveal changes in secretory cell activity.

\section{Indicators of epigenetic modifications that may impact secretory cell activity}

Epigenetic changes may participate in regulating mammary tissue plasticity. Indeed, epigenetic regulations may be partly 
responsible for the molecular regulation of milk constituent production. Studies in rodents or lagomorphs have shown that a combination of epigenetic events (chromatin opening, chromatin loop formation, histone acetylation and DNA methylation), on a global scale or targeted to specific genes, occurs during the development of the mammary gland and alters gene expression (Rijnkels et al., 2010). In cattle, DNA is hypomethylated in the $5^{\prime}$ region of the $\alpha$ s1 casein gene when this gene is expressed (Platenburg et al., 1996). It has been shown recently that the stage of mammary development modulates the degree of DNA methylation in the distal regulatory region upstream of this gene. This area of DNA contains three $\mathrm{CpG}$ islands near the binding sites of signal transducer and activator of transcription 5 (STAT5), a transcription factor involved in signal transduction of the hormone prolactin (Vanselow et al., 2006). In the mammary gland, these $\mathrm{CpG}$ sites are less methylated $(<30 \%)$ during lactation than during puberty, gestation or involution (between $35 \%$ and $60 \%$ ), while being hypermethylated in the liver (>65\%; Vanselow et al., 2006; Singh et al., 2012; Nguyen et al., 2014). The high level of DNA methylation at these three $\mathrm{CpG}$ sites during mammary involution was associated with a low expression of the CSN1S1 gene (Singh et al., 2012). Epigenetic changes, such as DNA methylation, may occur during lactation and may result in long-term modulation of gene expression, thus affecting cell activity for a long period.

\section{Indicators of the number of MECS}

Another cellular mechanism that may contribute to mammary tissue plasticity is changes in the number of MEC in the mammary tissue. This number results from changes in the rates of cell proliferation and cell loss. The loss of MEC in the mammary tissue has been first considered to be due to cell death. However, MEC can be lost from the mammary tissue through exfoliation of MEC from the mammary epithelium into milk during lactation (Herve et al., 2016). The number of MEC in the goat mammary gland increases slightly during early lactation up until the peak of lactation (Knight and Peaker, 1984). After this, the gradual decrease in milk yield is associated with a decrease in MEC number in the mammary gland, due to a greater cell apoptosis rate than cell proliferation rate (Knight and Peaker, 1984; Capuco et al., 2001) and a gradual increase in the MEC exfoliation rate (Herve et al., 2016). Standard indicators of variations in MEC number in the mammary tissue correspond to histological analyses that allow the rates of cell proliferation or cell death to be measured (Capuco et al., 2001). Moreover, DNA concentration or overall DNA content in the mammary tissue (Capuco et al., 2001) and the expression of genes involved in cell proliferation such as ATP-binding cassette super-family $G$ member 2 (ABCG2), CCAAT enhancer binding protein delta (CEBPD), clusterin (CLU) and integrin subunit beta 6 (ITGB6) and cell death such as $\mathrm{BCl}$-2-modifying factor $(B M F)$, insulinlike growth factor binding protein 5 (IGFBP5), Cathepsin B (CTSB), B-cell lymphoma 2 (BCL2) and BCL2 associated $X$ $(B A X)$ and caspases can also be indicators of variations in the number of MEC in the mammary gland (Boutinaud et al., 2013).

\section{Mammary stem cells may impact the number of MECs in the mammary tissue}

The ability of the mammary gland to undergo many cycles of cell proliferation and tissue involution through successive gestations and lactations highlights the existence of resident cells able to regenerate the entire epithelial tissue. As in other somatic tissues, stem cells are believed to exist during the entire lifecycle of the mammary gland, thus representing a key mechanism in the plasticity of this organ. The mammary stem cells (MaSC) are required to generate the various cell populations in different lineages (epithelial and myoepithelial) during pregnancy and might sustain cell turnover to replace cells during lactation. Although research on MaSC has focused mainly on the murine and human models, pioneer studies in bovine identified a population of lightly stained cells with high proliferative capacity within the mammary parenchyma of the heifer mammary gland that may be the putative MaSC (Ellis and Capuco, 2002). More recently, when flow cytometry was used to define the MaSC by the co-expression of cell surface proteins CD49f and CD24, it was found that the proportion of MaSC was stable during a cow lactation cycle (Perruchot et al., 2016) but was markedly decreased at drying-off (Finot et al., 2018). These studies agree with the notion that the MaSC and their progeny may play a key role in mammary tissue regeneration. The regulation of the number of MaSC and their involvement in mammary tissue plasticity during cow lactation remain to be clarified.

\section{What are the adaptation processes of the mammary tissue when lactation is challenged?}

The challenges, including changes in milking frequency and level of feed supply and hormonal and heath manipulations, have been shown to modulate milk yield in association with changes in the mammary tissue functioning. To identify the mechanisms involved in the plasticity of the ruminant mammary gland, we analyzed mammary tissue responses to challenges that were experimentally applied during lactation.

\section{Effect of challenges on secretory cell activity}

The adaptation of the mammary tissue to milking frequency has been widely studied (Table 1). The decrease in milk yield observed after a reduction in milking frequency from twice daily $(2 \times)$ to once daily $(1 \times)$ was accompanied by a reduction of ACC and FASN enzyme activity (Farr et al., 1995). Conversely, the increase in milk yield in response to a high milking frequency per day $(3 \times$ or $4 \times)$ was associated with an increase of mammary enzyme activity in the first days after the milking frequency was modified (Wilde et al., 1987; Travers and Barber, 1993). After several weeks of $3 \times$ milking, FASN, GT and ACC activities were no longer 
different than during $2 \times$ milking (Wilde et al., 1987; Nørgaard et al., 2005), whereas greater glucose-6-phosphate dehydrogenase, lactate dehydrogenase and hexokinase activities were reported (Wilde et al., 1987). Regardless of whether a target-gene or transcriptomic approach was used (Table 1), most studies showed an increase in the expression of the genes involved in the synthesis of milk when milking frequency was increased and, accordingly, a decrease when milking frequency was reduced.

The effect of feeding level manipulation on mammary secretory activity has not been as extensively investigated (Table 2). Feed or energy restriction has been found to induce a loss of milk yield. One study showed that the reduction of milk yield with energy restriction in midlactation dairy cows was associated with a tendency for lower GT enzyme activity (Nørgaard et al., 2005). Moderate feed restriction (30\% and 20\% less than the control diet) increased milk protein transcripts in early lactation (Sigl et al., 2014) but did not affect them in a later stage of lactation (Boutinaud et al., 2008; Herve et al., 2018). In contrast, a severe feed restriction in early lactation that reduced milk production by $38 \%$ was accompanied by decreases in LALBA and CSN3 gene expression (Dessauge et al., 2011), with no effect on CSN1S1 mRNA level. In another study, a severe feed restriction ( $40 \%$ less than the control diet) in mid-lactation dairy cows reduced the expression of genes involved in lipid metabolism (Abdelatty et al., 2017). Thus, the effect of feed restriction on secretory cell activity likely depends on the severity of the challenge and the timing of its application.

Table 1 Effects of the modification of milking frequency on indicators of secretory cell activity in the mammary tissue of dairy cows and goats)

\begin{tabular}{|c|c|c|c|c|c|}
\hline \multirow[b]{2}{*}{ Treatment $^{1}$} & \multirow[b]{2}{*}{ Species } & \multirow[b]{2}{*}{ Milk yield } & \multicolumn{3}{|c|}{ Indicators of secretory cell activity modifications ${ }^{2}$} \\
\hline & & & Enzyme activity & mRNA & Reference \\
\hline $4 \times$ v. $2 \times$ for 4 weeks & Cow & $\uparrow$ & $\begin{array}{l}\text { Tendency for } \uparrow \text { ACC, FASN, } \\
\text { GT and G6PH }\end{array}$ & & Hillerton et al., 1990 \\
\hline $3 \times$ v. $2 \times$ for 7 days and 3 weeks & Cow & $\uparrow$ & $\begin{array}{c}\uparrow A C C \text { and FASN at } 7 \mathrm{~d} \text { but } \\
\text { no variation at } 3 \text { weeks }\end{array}$ & & Wilde and Henderson, 1985 \\
\hline $3 \times$ v. $2 \times$ for 37 weeks & Cow & $\uparrow$ & $\begin{array}{l}\uparrow \text { Enzyme activity (G6PD, } \\
\text { hexokinase, LDH) }\end{array}$ & & Wilde et al., 1987 \\
\hline $3 \times$ v. $2 \times$ for 3 or 6 weeks & Cow & $\uparrow$ & & $\begin{array}{l}\text { No variation in mRNA } \\
\text { involved in milk lipid and } \\
\text { protein }^{3}\end{array}$ & Grala et al., 2014 \\
\hline $3 \times$ v. $2 \times$ for 8 weeks & Cow & $\uparrow$ & No difference & & Nørgaard et al., 2005 \\
\hline $3 \times$ v. $2 \times$ for 3 weeks & Goat & $\uparrow$ & $\uparrow A C C$ and FASN & $\uparrow A C C$ and $\mathrm{FASN}^{3}$ & Travers and Barber, 1993 \\
\hline $4 \times$ v. $2 \times$ for 7 days & Cow & $\uparrow$ & & $\begin{array}{l}\uparrow C S N 1 S 1, C S N 2 \text { and } \\
\qquad A L B A^{3}\end{array}$ & Murney et al., 2015 \\
\hline $4 \times$ v. $2 \times$ for 7 or 14 days & Cow & $\uparrow$ & & $\begin{array}{l}\uparrow C S N 1 S 1, C S N 2, L A L B A, \beta- \\
\text { lactoglobulin and glycam } \\
1^{4}\end{array}$ & Connor et al., 2008 \\
\hline $4 \times$ v. $1 \times$ over 230 days & Cow & $\uparrow$ & & $\uparrow L A L B A^{3}$ & Alex et al., 2015 \\
\hline $3 \times$ v. $1 \times$ for 3 weeks & Cow & $\uparrow$ & & No variation in $\mathrm{CSN}^{3}$ & Boutinaud et al., 2003 \\
\hline $3 \times$ v. $1 \times$ for 4 and 8 weeks & Cow & $\uparrow$ & & $\uparrow \mathrm{CSN} 2^{3}$ & Bernier-Dodier et al., 2010 \\
\hline $1 \times$ v. $2 \times$ for 7 or 20 days & Cow & $\downarrow$ & $\downarrow A C C$ and FASN & & Farr et al., 1995 \\
\hline $1 \times$ v. $2 \times$ for 1 week & Cow & $\downarrow$ & & $\downarrow C S N 3$ and $\angle A L B A^{3}$ & Boutinaud et al., 2012 \\
\hline $1 \times$ v. $2 \times$ for 3 or 6 weeks & Cow & $\downarrow$ & & $\begin{array}{l}\downarrow \text { LALBA, CSN2, CSN1S1, } \\
\quad B 4 G A L T 1, F A S N \text { and } A C C^{3}\end{array}$ & Grala et al., 2014 \\
\hline $1 \times$ v. $2 \times$ for 5 days & Cow & $\downarrow$ & & $\begin{array}{l}\downarrow \angle A L B A, B 4 G A L T 1, U G P 2, \\
\quad C S N 2, G P A M, L P L^{4}\end{array}$ & Littlejohn et al., 2010 \\
\hline $1 \times$ v. $2 \times$ for 1 week & Cow & $\downarrow$ & & $\begin{array}{l}\downarrow \text { PAH, PTGES, RBP1 (small } \\
\text { molecule biochemistry), } \\
\text { SCD, CD36, } \\
\text { FABP3, LPL (lipid), GPAM, } \\
\text { Chi3L1 (carbohydrate) } \\
\text { and SLC25A24 (amino } \\
\text { acid) }^{4}\end{array}$ & Boutinaud et al., 2013a \\
\hline $1 \times$ v. $2 \times$ for 1 and 5 weeks & Goat & $\downarrow$ & & $\downarrow L A L B A$ and $S L C 2 A 1^{3}$ & Ben Chedly et al., 2011 \\
\hline $1 \times$ v. $2 \times$ for 2 weeks & Goat & $\downarrow$ & & $\downarrow L A L B A^{3}$ & Ben Chedly et al., 2013 \\
\hline
\end{tabular}

$11 \times, 2 \times, 3 \times$ or $4 \times$ for milking one, two, three or four times daily, respectively.

${ }^{2}$ Abbreviations are listed in the Supplementary material (S1).

${ }^{3}$ Target-gene approach was taken.

${ }^{4}$ Transcriptomic approach was taken. 
Boutinaud, Herve, Quesnel, Lollivier, Finot, Dessauge, Chanat, Lacasse, Charton, and Guinard-Flament

Table 2 Effects of the modification of feeding level on indicators of secretory cell activity in the mammary tissue of dairy cows

\begin{tabular}{|c|c|c|c|c|}
\hline \multirow[b]{2}{*}{ Treatment $^{2}$} & \multirow{2}{*}{$\begin{array}{l}\text { Milk } \\
\text { yield }\end{array}$} & \multicolumn{3}{|c|}{ Indicators of secretory cell activity modifications ${ }^{1}$} \\
\hline & & Enzyme activity & mRNA & Reference \\
\hline $\begin{array}{l}\text { Energy restriction for } 8 \text { weeks (early } \\
\text { lactation) }\end{array}$ & $\downarrow$ & $\begin{array}{l}\text { Tendency for } \downarrow \\
\text { GT }\end{array}$ & & $\begin{array}{l}\text { Nørgaard et al., } \\
2005\end{array}$ \\
\hline $\mathrm{FR}^{2}$ for 11 weeks (early lactation) & $\downarrow$ & & $\downarrow L A L B A$ and $C S N 3$, no variation for CSN1S1 & $\begin{array}{l}\text { Dessauge et al., } \\
2011\end{array}$ \\
\hline FR for 2 days (early lactation) & $\downarrow$ & & $\downarrow \angle A L B A$ and $C S N 3$, no variation for CSN2 & Sigl et al., 2014 \\
\hline FR for 2 days (mid-lactation) & $\downarrow$ & & no variation for CSN1S1, CSN1S2, CSN2, CSN3 and LALBA & Sigl et al., 2014 \\
\hline FR for 1 week (mid-lactation) & $\downarrow$ & & $\downarrow S L C 2 A 1$, no effect on $\angle A L B A$ and $C S N 2$ & $\begin{array}{l}\text { Boutinaud et al., } \\
2008\end{array}$ \\
\hline FR for 15 and 18 days (mid-lactation) & $\downarrow$ & & $\downarrow A C C, G P A M, S C D, F A B P 3, L P L$ and $S R E B P 1$ & $\begin{array}{l}\text { Abdelatty et al., } \\
2017\end{array}$ \\
\hline FR for 4 weeks (mid-lactation) & $\downarrow$ & & $\begin{array}{l}\text { Tendency for } \downarrow L A L B A \text { in milk purified MEC but not in } \\
\text { mammary tissue }\end{array}$ & Herve et al., 2018 \\
\hline
\end{tabular}

${ }^{1}$ Abbreviations are listed in the Supplementary material S1.

${ }^{2} \mathrm{FR}$, feed restriction.

Mastitis is also a challenge that has a temporary negative effect on milk production and may, therefore, affect secretory cell activity (Table 3). Lipopolysaccharide-induced mastitis downregulated $L A L B A$ gene expression but not CSN1S1 gene expression in bovine mammary tissue (Gross et al., 2015). A downregulation of genes involved in lipid synthesis was also reported after challenges with lipopolysaccharide (Gross et al., 2015) or Streptococcus uberis (Moyes et al., 2009). In addition, a clear reduction in the content of milk proteins involved in the synthesis of milk (casein, $\alpha$-lactalbumin, GT and $\beta$-lactoglobulin) was observed by means of proteomic approaches (Table 3). These results suggest that mammary tissue inflammation affects the activity of the MEC.

To understand the role of hormones in the adaptation process of the mammary tissue, milk production was modulated by hormonal manipulations (Table 4). The withdrawal of ovarian steroid secretion following ovariectomy limited the rate of decrease in milk yield after the peak of lactation (Yart et al., 2012). The reduction of milk yield decline was not accompanied by the modification of milk protein gene expression Boutinaud et al., 2013b. In contrast, long-term inhibition of prolactin secretion using quinagolide, a dopamine agonist, induced a reduction in milk yield (Lacasse et al., 2011) accompanied by decreases in LALBA and CSN3 mRNA levels (Boutinaud et al., 2012).

For most of the challenges, the impact on milk yield (either positive or negative) was associated with a parallel variation of the secretory cell activity. This suggests that the change in cell activity, regulated through the modification of gene expression, enzyme activity and protein synthesis, is generally involved in the adaptation process of the mammary tissue.

\section{Effect of challenges on epigenetic marks}

The first study showing the effects of a challenge on epigenetic marks during lactation involved manipulation of the health status. An experimentally induced infection with Escherichia coli induced an increase in the level of methylation of the three CpG sites upstream of the CSN1S1 gene and a condensation of the chromatin associated with a decrease in the CSN1S1 RNA level (Vanselow et al., 2006). Similar effects were observed following infection with $S$. uberis (Singh et al., 2012). Milking frequency has also been shown to modify the epigenetic marks on the CSN1S1 locus. During differential milking, the milk yield of the half-udder milked $1 \times$ was lower than its contralateral half-udder milked $2 \times$. This reduction in milk yield was associated with greater $\mathrm{CpG}$ methylation levels upstream of the CSN1S1 gene and a lower RNA level of this gene in the $1 \times$-milked half-udder than in the $2 \times$-milked half-udder (Nguyen et al., 2014). In contrast, a severe and long-term feed restriction during early lactation in dairy cows did not affect the levels of CSN1S1 mRNA and CpG methylation upstream of this gene (Boutinaud et al., 2016). Although still scarce, studies evaluating epigenetic modulation in the mammary tissue suggest that epigenetic modifications are involved in the adaptive response of the mammary tissue to a challenge and modulate the secretory activity of MEC.

\section{Effect of challenges on mammary cell number}

The effect of milking frequency on mammary cell number is not always consistent from one study to another (Table 5). Nevertheless, when milking frequency is increased, it generally induced an increase in milk yield associated with an increase in the number of MEC in the tissue, and the contrary is observed when the milking frequency is reduced. Increasing milking frequency generally increases the rate of cell proliferation and reduces that of apoptosis (Table 5). In some studies, however, cell proliferation or cell apoptosis was not affected with either an increase or a decrease in milking frequency (Nørgaard et al., 2005; Wall and McFadden, 2012; Ben Chedly et al., 2013). Furthermore, cell proliferation was surprisingly reduced (Bernier-Dodier 
Table 3 Effects of inflammation induced by intramammary infection or infusion of $L P S^{2}$ on indicators of secretory cell activity in the mammary tissue of dairy ruminant

\begin{tabular}{|c|c|c|c|c|}
\hline \multirow[b]{2}{*}{ Treatment } & \multirow[b]{2}{*}{ Species } & \multicolumn{3}{|c|}{ Indicators of secretory cell activity modifications ${ }^{1}$} \\
\hline & & mRNA & Protein & Reference \\
\hline LPS $^{2}$ & Cow & $\downarrow L A L B A$, but not CSN1S1 or CSN2 & & Schmitz et al., 2004 \\
\hline LPS & Cow & $\downarrow$ FASN, ACC, and $\angle A L B A$ but not CSN1S1 & & Gross et al., 2015 \\
\hline Streptococcus uberis & Cow & $\downarrow G P A M, S C D, F A B P 4, C D 36$ and $\angle P L$ & & Moyes et al., 2009 \\
\hline S. uberis & Cow & & $\downarrow \beta$-1,4-galactosyltransferase, $\alpha$-lactalbumin & Mudaliar et al., 2016 \\
\hline Escherichia coli & Cow & & $\downarrow$ Casein, $\alpha$-lactalbumin, $\beta$-lactoglobulin & Boehmer et al., 2008 \\
\hline Clinical mastitis & Cow & & $\downarrow$ Casein, $\alpha$-lactalbumin, $\beta$-lactoglobulin & Hogarth et al., 2004 \\
\hline Clinical mastitis & Yak & & $\downarrow$ Casein, $\alpha$-lactalbumin, $\beta$-lactoglobulin & Li et al., 2014 \\
\hline
\end{tabular}

${ }^{1}$ Abbreviations are listed in the Supplementary material S1.

${ }^{2}$ LPS $=$ Lipopolysaccharides

Table 4 Effects of hormonal manipulations on indicators of secretory cell activity in the mammary tissue of dairy cows

\begin{tabular}{lcccc}
\hline \hline & & & \multicolumn{2}{c}{ Indicators of secretory cell activity modifications $^{1}$} \\
\cline { 3 - 5 } Treatment & Milk yield & Enzyme activity & & mRNA \\
\hline Prolactin inhibition & $\downarrow$ & - & $\downarrow$ LALBA and CSN3 & Boutinaud et al., 2012 \\
Prolactin inhibition & $\downarrow$ & - & $\downarrow$ LALBA and CSN3 & Lollivier et al., 2015 \\
Ovariectomy & $\uparrow$ & - & No variation in milk protein mRNA levels & Boutinaud et al., 2013b \\
\hline \hline
\end{tabular}

${ }^{1}$ Abbreviations are listed in the Supplementary material S1.

et al., 2010), and cell apoptosis surprisingly increased by an increased milking frequency (Connor et al., 2008). In most studies, milking frequency affected the expression of genes involved in cell proliferation and apoptosis, regardless of whether the analysis used the target-gene or transcriptomic approach (Table 5). Other indicators also suggest variations in cell number in the mammary tissue following modification of milking frequency. For instance, mean alveolar area, or the number of MEC per alveolus, were increased by greater milking frequency (Hillerton et al., 1990; Boutinaud et al., 2003). In line with this, total DNA content, or DNA concentration, was also shown to increase in the mammary gland of dairy goats when milking frequency was increased (Boutinaud et al., 2003). However, this was not observed by Nørgaard et al. (2005) in a study performed in dairy cows. For MEC exfoliation, 7 days of $1 \times$ milking in comparison with $2 \times$ milking did not affect MEC exfoliation in dairy goats and cows, whereas several weeks of $1 \times$ milking induced a marked increase in MEC exfoliation in goats (Herve et al., 2016). Thus, mammary cell number appears to be generally affected by milking frequency.

Similarly to milking frequency, feed restriction affected the indicators of variation of cell number differently depending on the study (Table 6). Indeed, the rate of mammary cell proliferation was reported to be decreased by a restriction of the energy in the diet (Nørgaard et al., 2005) but not by a feed restriction (Dessauge et al., 2011; Herve et al., 2018). In addition, the rate of cell apoptosis was enhanced by feed restriction during early lactation (Dessauge et al., 2011) but not when applied in a later stage of lactation (Herve et al., 2018) or by energy restriction (Nørgaard et al.,
2005). The effects of feed restriction on MEC exfoliation are also not consistent. The exfoliation of MEC was enhanced during a 4 weeks feed restriction (Herve et al., 2018) but not after 2 weeks of feed restriction of similar intensity (Herve et al., 2016). The finding that cell apoptosis and proliferation and MEC exfoliation are most often affected by feed restriction suggests that the number of mammary cells decreases with milk yield during feed restriction, as also suggested by the decrease in total DNA content (Dessauge et al., 2011).

Mastitis may also affect MEC number in the mammary tissue. The reduced ability of cows with mastitis to synthesize and secrete milk has been related to an increased apoptosis and sloughing of MEC in the mammary tissue (Akers and Nickerson, 2011). In addition, endotoxin administration strongly increased the percentage of milk MEC in the total somatic cell population (Wagner et al., 2009). This finding also suggests that mastitis affects the number of mammary cells by influencing MEC exfoliation.

Hormonal manipulations also affected indicators of cell number variations in the mammary tissue (Table 7). Greater milk yield in ovariectomized cows than in control cows was associated with a decrease in the expression of the enzyme poly ADP ribose polymerase (PARP) protein (Yart et al., 2012), which intervenes in DNA fragmentation during one of the final stages of cell death. This effect was accompanied by lower MEC exfoliation (Boutinaud et al., 2013b). Both indicators suggest lower losses of MEC in the mammary tissue in ovariectomized cows. The lower milk yield in cows treated with a prolactin inhibitor in comparison with untreated cows was associated with either a decrease (Boutinaud et al., 
Boutinaud, Herve, Quesnel, Lollivier, Finot, Dessauge, Chanat, Lacasse, Charton, and Guinard-Flament

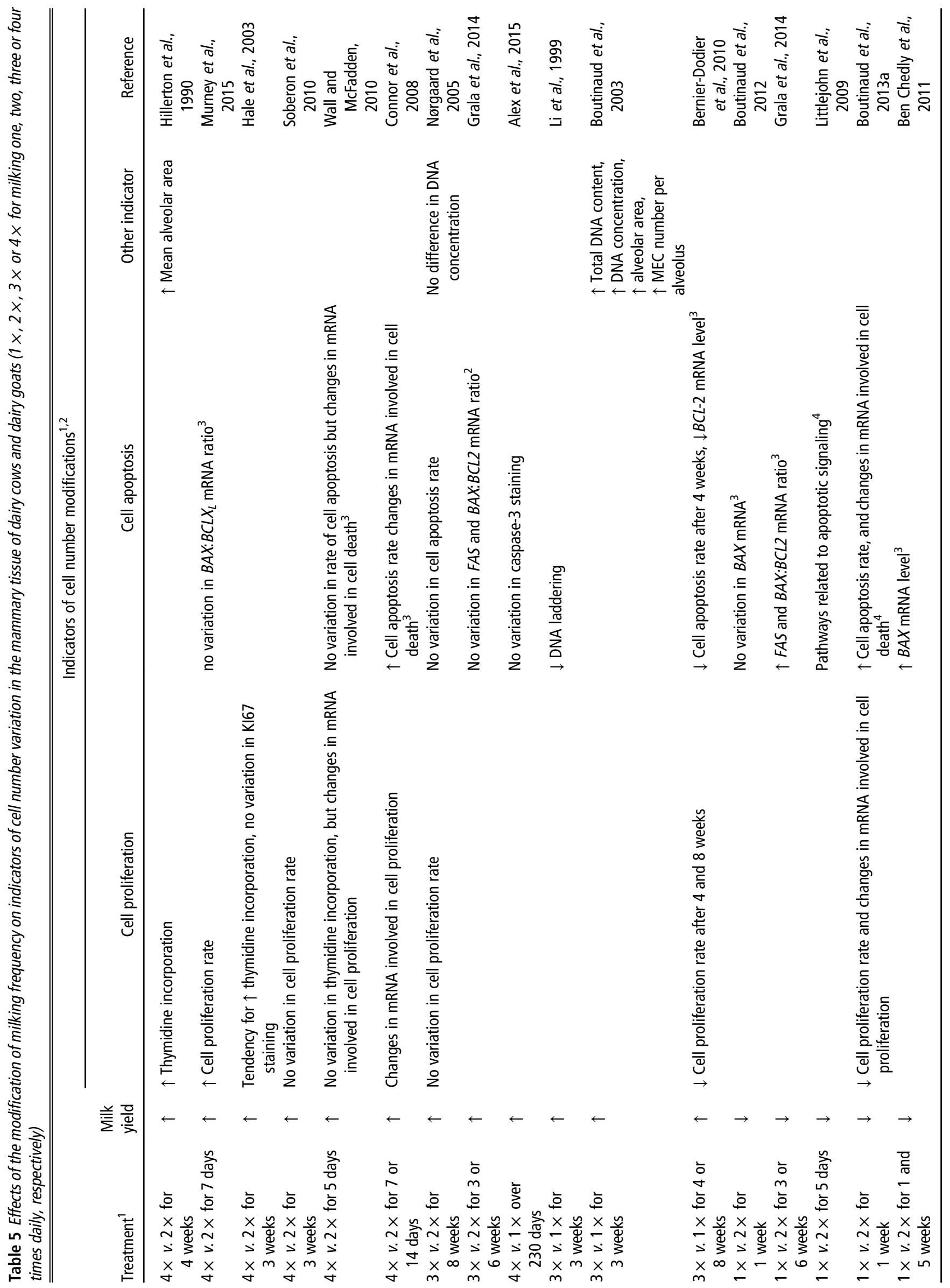


2012) or no variation (Lollivier et al., 2015) in the rate of cell proliferation, an increase in the rate in cell apoptosis (Boutinaud et al., 2012) and an increase (Lollivier et al., 2015) in MEC exfoliation. Taking together, these effects suggest a reduction in mammary cell number with the prolactin inhibitor.

The adaptation of the mammary tissue during a challenge does not necessarily involve all processes related to modifications in cell number (proliferation, death and MEC exfoliation), but most of the indicators show a change in the number of cells in the same direction as the change in milk production. The fact that variations in gene expression involved in cell turnover were always observed, whereas the rates of cell proliferation and apoptosis were not always affected, may be due to methodological limits of the immunohistological analyses or due to the lack of representativeness of the mammary tissue samples collected. Indeed, many of the studies were conducted using mammary biopsy. This would not have captured changes in total cell number or in rates of quiescence and senescence within the whole gland (Wall and McFadden, 2008).

\section{Initial conclusion about the adaptation processes of the mammary tissue when lactation is challenged}

The cellular mechanisms underlying mammary tissue plasticity in response to challenges are diverse. The mammary tissue adapts to the challenges by modifying its secretory activity and/or number of cells. Part of the mechanisms responsible for the change in secretory activity involves epigenetic modifications. In most studies, not all processes are studied at once, and there is no clear description of each potential process of adaptation. Moreover, the lack of variation of some indicators in some studies suggests that not all mechanisms are involved in the milk yield response at the same time. The response of the mammary tissue could depend on the type of challenge (energy or global feed restriction for cell proliferation and cell death), the intensity of the challenge (as observed for feed restriction), the length of the challenge (number of weeks of modified milking frequency for enzyme activity or number of weeks of feed restriction for MEC exfoliation), and the stage of lactation when the challenge is applied (observed for both feed restriction and changes in milking frequency). For some challenges, the adaptation of the mammary tissue also differs according to species, as seems to be the case for the effect of milking frequency on total DNA content. Since the adaptation of the mammary tissue is time-dependent, it is important to develop experimental designs that provide the possibility of performing dynamic studies. This would permit catching the window of time when the adaptive phenomenon occurs. In most of the studies, the analysis of mammary functions was performed at steady state, when the adaptation had already occurred, which most likely explains why no effects were observed. The most appropriate timing for these analyses may be when milk yield begins to be affected. 
Boutinaud, Herve, Quesnel, Lollivier, Finot, Dessauge, Chanat, Lacasse, Charton, and Guinard-Flament

Table 6 Effects of the modification of the feeding level on indicators of cell number variation in the mammary tissue of dairy cows

\begin{tabular}{|c|c|c|c|c|c|}
\hline \multirow[b]{2}{*}{ Treatment } & \multirow{2}{*}{$\begin{array}{l}\text { Milk } \\
\text { yield }\end{array}$} & \multicolumn{4}{|c|}{ Indicators of cell number modifications ${ }^{1}$} \\
\hline & & Cell proliferation & Cell apoptosis & Other indicators & Reference \\
\hline $\begin{array}{l}\text { Energy restriction for } 8 \text { weeks (early } \\
\text { lactation) }\end{array}$ & $\downarrow$ & $\downarrow$ Cell proliferation rate & $\begin{array}{l}\text { No variation in cell } \\
\text { apoptosis rate }\end{array}$ & & $\begin{array}{l}\text { Nørgaard et al., } \\
2005\end{array}$ \\
\hline $\mathrm{FR}^{2}$ for 11 weeks (early lactation) & $\downarrow$ & $\begin{array}{l}\text { No variation in cell } \\
\text { proliferation rate }\end{array}$ & $\uparrow$ Cell apoptosis rate & $\begin{array}{l}\downarrow \text { DNA total content, } \\
\uparrow \text { DNA concentration }\end{array}$ & $\begin{array}{l}\text { Dessauge et al., } \\
2011\end{array}$ \\
\hline FR for 2 weeks (mid-lactation) & $\downarrow$ & & & $\begin{array}{l}\text { No variation in MEC } \\
\text { exfoliation }\end{array}$ & $\begin{array}{l}\text { Herve et al., } \\
\quad 2016\end{array}$ \\
\hline FR for 4 weeks (mid-lactation) & $\downarrow$ & $\begin{array}{l}\text { No variation in cell } \\
\text { proliferation rate }\end{array}$ & $\begin{array}{l}\text { No variation in cell } \\
\text { apoptosis rate }\end{array}$ & $\begin{array}{l}\uparrow \text { MEC exfoliation, } \\
\uparrow \text { DNA concentration }\end{array}$ & $\begin{array}{l}\text { Herve et al., } \\
2018\end{array}$ \\
\hline
\end{tabular}

${ }^{1}$ Abbreviations are listed in the Supplementary material S1.

${ }^{2} \mathrm{FR}$, feed restriction.

Table 7 Effects of hormonal manipulations on indicators of cell number variation in the mammary tissue of dairy cows

\begin{tabular}{|c|c|c|c|c|c|}
\hline \multirow[b]{2}{*}{ Treatment } & \multirow[b]{2}{*}{ Milk yield } & \multicolumn{4}{|c|}{ Indicators of cell number modifications ${ }^{1}$} \\
\hline & & Cell proliferation & Cell apoptosis & MEC exfoliation & Reference \\
\hline Ovariectomy & $\uparrow$ & & $\downarrow$ PARP protein & & Yart et al., 2012 \\
\hline Ovariectomy & $\uparrow$ & & & $\downarrow$ & Boutinaud et al., 2013b \\
\hline Prolactin inhibition & $\downarrow$ & $\downarrow$ Cell proliferation rate & $\uparrow$ Cell apoptosis rate & No variation & Boutinaud et al., 2012 \\
\hline Prolactin inhibition & $\downarrow$ & No difference (PCNA) & & $\uparrow$ & Lollivier et al., 2015 \\
\hline
\end{tabular}

${ }^{1}$ Abbreviations are listed in the Supplementary material S1.

\section{Do the mechanisms underlying mammary tissue plasticity participate to the carryover effects?}

\section{Theoretical impact of challenges on the resilience of the mammary tissue}

The first two parts of this review focused on the first step of the process of adaptation, that is resistance, to explain how the mammary tissue adapts to a challenge. It has been shown that the mammary tissue is a deformable system and that its adaptation to new conditions is accompanied by a variation in the amount of milk produced. The next part of this review focuses on the resilience of the mammary tissue and discusses whether the adaptation of the tissue is reversible or not. Irreversible processes could explain the carryover effects on milk yield when the challenge is terminated. The effects may become irreversible when the intensity of the challenge (length or strength) reaches a threshold that could lead to homeostatic ruptures. Most of the works dedicated to the effects of challenges have analyzed the effects on mammary functions only during the application of the challenge. It is, therefore, not possible to deduce the permanency of the effects on mammary functioning from those experiments. For a long time, it has been assumed that short-term modulations of milk production without carryover effects were due to changes in cell activity, while modulations of lactation that extended beyond the end of the challenge were due to changes in the number of MEC. However, a recent discovery has shown that environmental events can lead to stable changes in gene expression through modification of DNA methylation. This suggests that carryover effects might not only due to changes in the number of MEC. Therefore, it is necessary to not only determine if a challenge has carryover effects but also the mechanisms involved. We will focus on the effect of milking frequency and feed restriction, which are the most investigated challenges.

\section{Changing milking frequency: an interesting model to investigate mammary tissue resilience}

The carryover effects of changing milking frequency on milk yield have been described in the literature (Stelwagen, 2001; Rémond and Pomiès, 2005; Wall and McFadden, 2012; Charton, 2017). Such effects clearly depend on the duration of the treatment. Indeed, reducing milking frequency from $2 \times$ to $1 \times$ for 1 week has no persistent effect on milk yield, whereas a residual milk loss of $10 \%$ was observed after 7-10 weeks of $1 \times$ milking (Rémond and Pomiès, 2005). The impact of the modification of milking frequency for a short period is also modulated by the lactation stage during which the challenge is applied. The deleterious impact of a shortterm application of $1 \times$ milking was greater during early lactation than at a later stage of lactation (Rémond and Pomiès, 2005). With respect to a persistent increase in milk yield with increased milking frequency, Wall and McFadden (2012) suggested that the timing (between day 7 and 21 of lactation) may be more critical than the duration. The 
mammary gland may be especially responsive to the stimulus of milk removal for a window of time at the beginning of lactation. Frequent milking during this time can, indeed, elicit a persistent increase in milk production for the remainder of the lactation (Wall and McFadden, 2008). However, one study reported that increased milking frequency for the first 3 weeks induced only a transient carryover effect (over less than 2 weeks) (Nørgaard et al., 2005).

In parallel with a more pronounced carryover effect when milking frequency challenge is longer (Rémond and Pomiès, 2005), it was suggested that milking frequency first induced changes in secretory activity followed by an effect on the number of mammary cells (Stelwagen, 2001). These observations argue in favor of the idea that the variation in cell number during a milking frequency challenge induces persistent effects. Accordingly, a persistent increase in milk yield occurred when cell proliferation tended to be increased by more frequent milking (Hale et al., 2003). In addition, no carryover effect was observed after increased milking frequency when a lack of effect on cell number had been observed (Nørgaard et al., 2005). However, a persistent effect on milk yield was also observed even though no changes in mammary proliferation and apoptosis rate was measured during the challenge period (Wall and McFadden, 2012). This contrasts with the idea that the change in MEC number is what causes the carryover effects. Moreover, the induction of MEC exfoliation during $1 \times$ milking in dairy goats was not accompanied by a carryover effect on milk yield (Ben Chedly et al., 2013). The carryover effect of milking frequency could thus be explained by other mechanisms than change in cell number. Indeed, two studies performed in bovine showed that the carryover effect on milk yield induced by a $1 \times$ milking period (Grala et al., 2011) or a $3 \times$ milking period (Wall et al., 2013) were related to a persistent effect on gene expression in the mammary tissue. Grala et al. (2011) reported persistent reductions in CSN1S1, LALBA, FASN, ACACA mRNA levels after $1 \times$, whereas Wall et al. (2013) observed a persistent modification of genes related to IGF-I signaling pathway after $3 \times$. In goats, the absence of carryover effect when goats were switched back to $2 \times$ milking after the application of 4 weeks of $1 \times$ milking was associated with a recovery of $\angle A L B A$ gene expression (Ben Chedly et al., 2013). These results suggest that carryover effects on milk production can be due to a persistent regulation of transcription. The carryover effect of a period of $1 \times$ milking has been related to an increase in DNA methylation in the distal region of the CSN1S1 gene (Nguyen et al., 2014). The persistent effect on gene expression in the mammary tissue would be the consequence of an imprinting process through epigenetic modifications. However, further studies are necessary to confirm the involvement of epigenetic modifications in persistent effects on milk yield.

Potential mechanisms underlying the resilience of the mammary tissue after modification of feed supply

The long-term effect of feed restriction on milk yield has been well documented. No carryover effect on milk yield has been observed regardless of the duration of the dietary challenge (from 4 days to 4 weeks; Friggens et al., 1998; Bjerre-Harpøth et al., 2012) and the stage of lactation (early, mid- or late lactation; Bjerre-Harpøth et al., 2012). Accordingly, a recent study showed no carryover effect of a $20 \%$ feed restriction of 4 weeks (Herve et al., 2018). This lack of persistent effect on milk yield was observed despite the negative effect of feed restriction on the number of MEC in the mammary tissue (as indicated by a higher rate of MEC exfoliation into milk; Herve et al., 2018). It is noteworthy that this was accompanied by an increase in the release of prolactin into blood at milking when cows were switched back to an ad libitum diet. Since prolactin is known to have galactopoietic effects, its enhanced release during the period following feed restriction may have counteracted the negative effect of the challenge on mammary cell number. This suggests that the mammary tissue, after a period of adaptation during the dietary challenge, enters a new process of adaptation when the animal is switched back to an ad libitum diet.

\section{Some factors responsible for individual variability in the adaptation of the mammary gland to challenges}

The study of individual response in the adaptation of the mammary tissue to reduced milking frequency such as during a 24-h milking interval revealed relationships between carryover effects on milk yield and some traits of the animal. Even if on average no carryover effect was observed after 1 day of $1 \times$ milking, the recovery of milk yield when $2 \times$ milking was resumed differed among cows. Cows were clustered according to their ability to recover milk yield after a 24-h milking interval. Cows that recovered poorly (on average $63.9 \%$ of the milk they had lost) exhibited a lower estimated milk yield potential or an initially inflamed udder (as indicated by a higher occurrence of initial milk interleukin-8; Charton et al., 2016). Therefore, several traits related to the physiological status of the mammary tissue (inflammation status, genetic parameters and stage of lactation) modulate the adaptation of the mammary tissue to a challenge and could result in carryover effects on milk yield. Thus, probably also for other challenges, the physiological status of the mammary tissue has to be taken into account to understand the mammary tissue plasticity.

\section{Conclusion}

The cellular mechanisms underlying mammary tissue plasticity during lactation may involve different cellular processes, such as modifications of secretory activity, epigenetic marks and mammary cell number. The processes will be different depending on the nature of the challenge (type, intensity and duration) and on animal-related factors (e.g., health, genetic background and stage of lactation). Depending on these conditions, the mammary tissue shows elastic properties, that is, non-permanent deformation or undergoes some 
irreversible modifications of milk production. The nonpermanent deformation is observed with dietary challenges, for instance. The irreversible modification can either be beneficial (e.g., after an increase in milking frequency during early lactation) or deleterious (e.g., after a reduction in milking frequency for a long period). However, the lack of suitable techniques for dynamic and complete analysis of the phenomena of adaptation has certainly limited a holistic and integral view of the physio-cellular adaptations in bovine mammary tissue. When considered alone, the cellular mechanisms underlying mammary tissue plasticity during challenges are not sufficient to understand the carryover effects on milk production. Epigenetic modifications may be an exception, since they could explain the residual effects of the modifications induced by changes in milking frequency. Special attention should thus be paid to epigenetic modifications because little is known about the persistency of these marks during lactation. Further investigations on the role of stem cells in mammary tissue plasticity need to be performed. Better knowledge of the mechanisms involved in that phenomenon will help us understand more about the high plasticity of mammary tissue, and especially the one that is observed during early lactation. The impact of that mammary tissue plasticity on animal productivity, longevity and robustness should also be addressed in the future.

\section{Acknowledgments}

The authors are very grateful to Pierre-Guy Marnet (Agrocampus Ouest, Rennes, France); Hedi Ben Chedly (AgroSup Dijon, Dijon, France); Eve Devinoy, Minh Nguyen, Laurent Galio, Clémence Kress, Denis Laloë, and Florence Jaffrezic (INRA, Jouy-en-Josas, France); and Kuljeet Singh (AgResearch, Hamilton, New Zealand) for their collaboration. The authors are grateful to Mary Varcoe, from the Translation Bureau, Public Services and Procurement Canada, for her careful editing of this manuscript. This review is based on a presentation at the International Workshop on the Biology of Lactation in Farm Animals (BOLFA), 25- 26 August 2018 preceding the 69th Annual Meeting of the European Federation of Animal Science (EAAP), Dubrovnik, Croatie. The abstract of this communication has been deposited in Prodinra https://prodinra.inra.fr/record/454711.

\section{Declaration of interest}

The authors declare that there is no conflict of interest for this manuscript.

\section{Ethics statement \\ None.}

\section{Software and data repository resources}

None of the data were deposited in an official repository.

\section{Supplementary material}

To view supplementary material for this article, please visit https://doi.org/10.1017/S1751731119000624

\section{References}

Abdelatty AM, Iwaniuk ME, Garcia M, Moyes KM, Teter BB, Delmonte $P$, Kadegowda AKG, Tony MA, Mohamad FF and Erdman RA 2017. Effect of shortterm feed restriction on temporal changes in milk components and mammary lipogenic gene expression in mid-lactation Holstein dairy cows. Journal of Dairy Science 100, 4000-4013.

Akers RM and Nickerson SC 2011. Mastitis and its impact on structure and function in the ruminant mammary gland. Journal of Mammary Gland Biology and Neoplasia 16, 275-289.

Alex AP, Collier JL, Hadsell DL and Collier RJ 2015. Milk yield differences between $1 \mathrm{x}$ and $4 \mathrm{x}$ milking are associated with changes in mammary mitochondrial number and milk protein gene expression, but not mammary cell apoptosis or SOCS gene expression. Journal of Dairy Science 98, 4439-4448.

Ben Chedly H, Lacasse P, Marnet PG, Komara M, Marion S and Boutinaud M 2011. Use of milk epithelial cells to study regulation of cell activity and apoptosis during once-daily milking in goats. Animal 5, 572-579.

Ben Chedly H, Lacasse P, Marnet P-G and Boutinaud M 2013a. The decrease in milk yield during once daily milking is due to regulation of synthetic activity rather than apoptosis of mammary epithelial cells in goats. Animal 7, 124-133.

Bernier-Dodier P, Delbecchi L, Wagner GF, Talbot BG and Lacasse P 2010. Effect of milking frequency on lactation persistency and mammary gland remodeling in mid-lactation cows. Journal of Dairy Science 93, 555-564.

Bionaz M, Periasamy K, Rodriguez-Zas SL, Everts RE, Lewin HA, Hurley WL and Loor JJ 2012. Old and new stories: Revelations from functional analysis of the bovine mammary transcriptome during the lactation cycle. PLoS ONE 7, e33268.

Bjerre-Harpøth V, Friggens NC, Thorup VM, Larsen T, Damgaard BM, Ingvartsen $\mathrm{KL}$ and Moyes KM 2012. Metabolic and production profiles of dairy cows in response to decreased nutrient density to increase physiological imbalance at different stages of lactation. Journal of Dairy Science 95, 2362-2380.

Boehmer JL, Bannerman DD, Shefcheck K and Ward JL 2008. Proteomic analysis of differentially expressed proteins in bovine milk during experimentally induced Escherichia coli mastitis. Journal of Dairy Science 91, 4206-4218.

Boutinaud M, Ben Chedly MH, Delamaire E and Guinard-Flament J 2008. Milking and feed restriction regulate transcripts of mammary epithelial cells purified from milk. Journal of Dairy Science 91, 988-998.

Boutinaud M, Galio L, Lollivier V, Finot L, Wiart S, Esquerre D and Devinoy E 2013. Unilateral once daily milking locally induces differential gene expression in both mammary tissue and milk epithelial cells revealing mammary remodeling. Physiological Genomics 45, 973-985.

Boutinaud M, Yart L, Debournoux P, Wiart S, Finot L, Le Guennec E, Marnet P-G, Dessauge $F$ and Lollivier V 2013b. Exfoliation of mammary epithelial cells in milk is linked with lactation persistency in dairy cows. In proceedings of the 64th EAAP Annual Meeting 28-30 August 2013, Nantes, France, pp 503.

Boutinaud M, Lollivier V, Dessauge F, Devinoy E and Singh K 2016. Régulations épigénétiques et activation de la transcription lors d'une restriction alimentaire chez la vache laitière. In Proceedings of the Journées d'Animation des Crédits Incitatifs du Département de Physiologie Animale et Systèmes d'Elevage, 5-6 April 2016, Tours, France, pp. 65.

Boutinaud M, Lollivier V, Finot L, Bruckmaier RM and Lacasse P 2012. Mammary cell activity and turnover in dairy cows treated with the prolactin-release inhibitor quinagolide and milked once daily. Journal of Dairy Science 95, 177-187.

Boutinaud M, Rousseau C, Keisler DH and Jammes H 2003. Growth hormone and milking frequency act differently on goat mammary gland in late lactation. Journal of Dairy Science 86, 509-520.

Boutinaud M, Dris-Kerdreux V, Wiart S, Aubry JM, Laloë D, Jaffrezic F, Devinoy E and Galio $L$ 2017. Effect of once daily milking on mammary transcriptome and cell turnover in dairy goat. In ASAS-CSAS Annual Meeting and Trade Show, 8-12 July 2017, Baltimore, USA pp. 169-170. 
Capuco AV, Wood DL, Baldwin R, McLeod K and Paape MJ 2001. Mammary cell number, proliferation, and apoptosis during a bovine lactation: relation to milk production and effect of bST. Journal of Dairy Science 84, 2177-2187.

Charton C 2017. Caractérisation de l'adaptation de la glande mammaire des vaches laitières à l'allongement de l'intervalle entre traites. PhD Thesis, Institut Supérieur des Sciences Agronomiques, Agroalimentaires, Horticoles et du Paysage, Rennes, France.

Charton $\mathrm{C}$, Larroque $\mathrm{H}$, Robert-Granié $\mathrm{C}$, Pomiès $\mathrm{D}$, Leclerc $\mathrm{H}$, Friggens NC and Guinard-Flament J 2016. Individual responses of dairy cows to a 24-hour milking interval. Journal of Dairy Science 99, 3103-3112.

Connor EE, Siferd S, Elsasser TH, Evock-Clover CM, Van Tassell CP, Sonstegard TS, Fernandes VM and Capuco AV 2008. Effects of increased milking frequency on gene expression in the bovine mammary gland. BMC Genomics 9, 362.

Dessauge F, Lollivier V, Ponchon B, Bruckmaier R, Finot L, Wiart S, Cutullic E, Disenhaus $C$, Barbey $S$ and Boutinaud M 2011. Effects of nutrient restriction on mammary cell turnover and mammary gland remodeling in lactating dairy cows. Journal of Dairy Science 94, 4623-4635.

Ellis S and Capuco AV 2002. Cell proliferation in bovine mammary epithelium: Identification of the primary proliferative cell population. Tissue and Cell 34, 155-163.

Farr VC, Stelwagen K, Kerr MA, Davis SR and Eichler SJ 1995. Effect of once daily milking (ODM) on enzyme activities in the bovine mammary gland. Proceedings of the New Zealand. Society of Animal Production 55, 12-13.

Finot L, Chanat E and Dessauge F 2018. Molecular signature of the putative stem/progenitor cells committed to the development of the bovine mammary gland at puberty. Scientific Reports 8, 16194.

Friggens NC, Emmans GC, Kyriazakis I, Oldham JD and Lewis M 1998. Feed intake relative to stage of lactation for dairy cows consuming total mixed diets with a high or low ratio of concentrate to forage. Journal of Dairy Science 81, 2228-2239.

Friggens NC, Sauvant D and Martin 0 2010. Vers des définitions opérationnelles de la robustesse s'appuyant sur des faits biologiques. L'exemple de la nutrition. INRA Productions Animales 23, 43-52.

Grala TM, Phyn CVC, Kay JK, Rius AG, Littlejohn MD, Snell RG and Roche JR 2011. Temporary alterations to milking frequency, immediately post-calving, modified the expression of genes regulating milk synthesis and apoptosis in the bovine mammary gland. Proceedings of the New Zealand Society of Animal Production, Vol. 71, pp. 3-8.

Grala TM, Phyn CV, Kay JK, Rius AG, Lucy MC, Littlejohn MD, Snell RG and Roche JR 2014. Gene expression in liver and adipose tissue is altered during and after temporary changes to postpartum milking frequency. Journal of Dairy Science 97, 2701-2717.

Gross JJ, van Dorland HA, Wellnitz 0 and Bruckmaier RM 2015. Glucose transport and milk secretion during manipulated plasma insulin and glucose concentrations and during LPS-induced mastitis in dairy cows. Journal of Animal Physiology and Animal Nutrition (Berlin) 99, 747-756.

Hale SA, Capuco AV and Erdman RA 2003. Milk yield and mammary growth effects due to increased milking frequency during early lactation. Journal of Dairy Science 86, 2061-2071.

Herve L, Quesnel H, Lollivier V and Boutinaud M 2016. Regulation of cell number in the mammary gland by controlling the exfoliation process in milk in ruminants. Journal of Dairy Science 99, 854-863.

Herve L, Quesnel H, Veron M, Portanguen J, Gross J, Bruckmaier RM and Boutinaud M 2018. Milk yield loss in response to feed restriction is associated with mammary epithelial cell exfoliation in dairy cows. Journal of Dairy Science 102, 2670-2685.

Hillerton JE, Knight CH, Turvey A, Wheatley SD and Wilde CJ 1990. Milk yield and mammary function in dairy cows milked four times daily. Journal of Dairy Research 57, 285-294.

Hogarth CJ, Fitzpatrick JL, Nolan AM, Young FJ, Pitt A and Eckersall PD 2004. Differential protein composition of bovine whey: a comparison of whey from healthy animals and from those with clinical mastitis. Proteomics 4, 2094-2100.

Knight $\mathrm{CH}$ and Peaker M 1984. Mammary development and regression during lactation in goats in relation to milk secretion. Quarterly Journal of Experimental Physiology 69, 331-338.

Lacasse P, Lollivier V, Bruckmaier RM, Boisclair YR, Wagner GF and Boutinaud M 2011. Effect of the prolactin-release inhibitor quinagolide on lactating dairy cows. Journal of Dairy Science 94, 1302-1309.
Li P, Rudland PS, Fernig DG, Finch LM and Wilde CJ 1999. Modulation of mammary development and programmed cell death by the frequency of milk removal in lactating goats. Journal of Physiology 519 (Pt 3), 885-900.

Li X, Ding XZ, Wan YL, Liu YM and Du GZ 2014. Comparative proteomic changes of differentially expressed whey proteins in clinical mastitis and healthy yak cows. Genetics and Molecular Research 13, 6593-6601.

Littlejohn MD, Walker CG, Ward HE, Lehnert KB, Snell RG, Verkerk GA, Spelman RJ, Clark DA and Davis SR 2010. Effects of reduced frequency of milk removal on gene expression in the bovine mammary gland. Physiological Genomics. 41, 21-32.

Lollivier V, Lacasse P, Angulo Arizala J, Lamberton P, Wiart S, Portanguen J, Bruckmaier $R$ and Boutinaud M 2015. In vivo inhibition followed by exogenous supplementation demonstrates galactopoietic effects of prolactin on mammary tissue and milk production in dairy cows. Journal of Dairy Science 98, 8775-8787.

Moyes KM, Drackley JK, Morin DE, Bionaz M, Rodriguez-Zas SL, Everts RE, Lewin HA and Loor JJ 2009. Gene network and pathway analysis of bovine mammary tissue challenged with Streptococcus uberis reveals induction of cell proliferation and inhibition of PPAR $\gamma$ signaling as potential mechanism for the negative relationships between immune response and lipid metabolism. BMC Genomics $10,542$.

Mudaliar M, Tassi R, Thomas FC, McNeilly TN, Weidt SK, McLaughlin M, Wilson D, Burchmore R, Herzyk P, Eckersall PD and Zadoks RN 2016. Mastitomics, the integrated omics of bovine milk in an experimental model of Streptococcus uberis mastitis: 2. Label-free relative quantitative proteomics. Molecular Biosystems 12, 2748-2761.

Murney R, Stelwagen K, Wheeler TT, Margerison JK and Singh K 2015. The effects of milking frequency in early lactation on milk yield, mammary cell turnover, and secretory activity in grazing dairy cows. Journal of Dairy Science 98, 305-311.

Nguyen $M$, Boutinaud $M$, Pétridou B, Gabory A, Pannetier $M$, Chat $S$, Bouet $S$, Jouneau L, Jaffrezic F, Laloë D, Klopp C, Brun N, Kress C, Jammes H, Charlier M and Devinoy $E$ 2014. DNA methylation and transcription in a distal region upstream from the bovine AlphaS1 casein gene after once or twice daily milking. PLOS ONE 9, e111556.

Nørgaard J, Sørensen A, Sørensen MT, Andersen JB and Sejrsen K 2005. Mammary cell turnover and enzyme activity in dairy cows: Effects of milking frequency and diet energy density. Journal of Dairy Science 88, 975-982.

Perruchot M-H, Arévalo-Turrubiarte M, Dufreneix F, Finot L, Lollivier V, Chanat E, Mayeur F and Dessauge F 2016. Mammary epithelial cell hierarchy in the dairy cow throughout lactation. Stem Cells and Development 25, 1407-1418.

Platenburg GJ, Vollebregt EJ, Karatzas CN, Kootwijk EPA, De Boer HA and Strijker R 1996. Mammary gland-specific hypomethylation of $\mathrm{Hpa}$ II sites flanking the bovine $\alpha 51$-casein gene. Transgenic Research 5, 421-431.

Rémond B and Pomiès D 2005. Once-daily milking of dairy cows: a review of recent French experiments. Animal Research 54, 427-442.

Rijnkels M, Kabotyanski E, Montazer-Torbati MB, Hue Beauvais C, Vassetzky Y, Rosen JM and Devinoy E 2010. The epigenetic landscape of mammary gland development and functional differentiation. Journal of Mammary Gland Biology and Neoplasia 15, 85-100.

Sauvant $D$ and Martin 0 2010. Robustesse, rusticité, flexibilité, plasticité... les nouveaux critères de qualité des animaux et des systèmes d'élevage: définitions systémique et biologique des différents concepts. INRA Productions Animales 23, 5-10.

Schmitz S, Pfaffl MW, Meyer HH and Bruckmaier RM 2004. Short-term changes of mRNA expression of various inflammatory factors and milk proteins in mammary tissue during LPS-induced mastitis. Domestic. Animal Endocrinology. $26,111-126$.

Sigl T, Meyer HHD and Wiedemann S 2014. Gene expression analysis of protein synthesis pathways in bovine mammary epithelial cells purified from milk during lactation and short-term restricted feeding. Journal of Animal Physiology and Animal Nutrition (Berlin) 98, 84-95.

Singh K, Molenaar AJ, Swanson KM, Gudex B, Arias JA, Erdman RA and Stelwagen $K$ 2012. Epigenetics: $A$ possible role in acute and transgenerational regulation of dairy cow milk production. Animal 6, 375-381.

Soberon F, Lukas JL, Van Amburgh ME, Capuco AV, Galton DM and Overton TR 2010. Effects of increased milking frequency on metabolism and mammary cell proliferation in Holstein dairy cows. Journal of Dairy Science 93, 565-73. 
Boutinaud, Herve, Quesnel, Lollivier, Finot, Dessauge, Chanat, Lacasse, Charton, and Guinard-Flament

Stelwagen K 2001. Effect of milking frequency on mammary functioning and shape of the lactation curve. Journal of Dairy Science 84, E204-E211.

Travers MT and Barber MC 1993. Isolation of a goat acetyl-CoA carboxylase complementary DNA and effect of milking frequency on the expression of the acetyl-CoA carboxylase and fatty acid synthase genes in goat mammary gland. Comparative Biochemistry and Physiology B 105, 123-128.

Vanselow J, Yang W, Herrmann J, Zerbe H, Schuberth H-J, Petzl W, Tomek W and Seyfert H-M 2006. DNA-remethylation around a STAT5-binding enhancer in the $\alpha \mathrm{S} 1$-casein promoter is associated with abrupt shutdown of $\alpha \mathrm{S} 1$-casein synthesis during acute mastitis. Journal of Molecular Endocrinology 37, 463-477.

Wagner SA, Jones DE and Apley MD 2009. Effect of endotoxic mastitis on epithelial cell numbers in the milk of dairy cows. American Journal of Veterinary Research 70, 796-799.

Wall EH and McFadden TB 2010. The effects of milk removal or four-times-daily milking on mammary expression of genes involved in the insulin-like growth factor-I axis. Journal of Dairy Science 93, 4062-4070.
Wall EH, Bond JP and McFadden TB 2013. Milk yield responses to changes in milking frequency during early lactation are associated with coordinated and persistent changes in mammary gene expression. BMC Genomics 14, 296.

Wall EH and McFadden TB 2008. Use it or lose it: enhancing milk production efficiency by frequent milking of dairy cows. Journal of Animal Science 86, 27-36.

Wall EH and McFadden TB 2012. Triennial Lactation Symposium: A local affair: how the mammary gland adapts to changes in milking frequency. Journal of Animal Science 90, 1695-1707.

Wilde CJ and Henderson AJ 1985. Lipogenic enzyme activities in goat mammary gland: changes with stage of pregnancy and lactation and frequency of milking. Biochemical Society Transactions 13, 877-878.

Wilde CJ, Henderson AJ, Knight CH, Blatchford DR, Faulkner A and Vernon RG 1987. Effects of long-term thrice-daily milking on mammary enzyme activity, cell population and milk yield in the goat. Journal of Animal Science 64, 533-539.

Yart L, Dessauge F, Finot L, Barbey S, Marnet PG and Lollivier V 2012. Ovariectomy improves lactation persistency in dairy cows. Journal of Dairy Science 95, 3794-3802. 